\title{
Self-reported type 2 diabetes Mellitus is associated with abdominal obesity and poor perception of health in shift workers
}

\author{
Diabetes Mellitus tipo 2 associada com \\ obesidade abdominal e autopercepção \\ de saúde em trabalhadores \\ de turnos
}

\author{
Carine FRÖHLICH ${ }^{1}$ \\ Raquel CANUTO2 \\ Anderson da Silva GARCEZ ${ }^{1}$ \\ Marcos Pascoal PATTUSSI ${ }^{1}$ \\ Ruth Liane HENN ${ }^{1}$ \\ Maria Teresa Anselmo OLINTO ${ }^{1}$
}

\section{A B S T R A C T}

\section{Objective}

To investigate factors that are associated with type 2 diabetes Mellitus in shift workers of a slaughterhouse in Southern Brazil.

\section{Methods}

This cross-sectional study included 1,194 18- to 50-year-old workers of both sexes. The presence of type 2 diabetes Mellitus was self-reported and confirmed by the use of hypoglycemic drugs or insulin. The independent variables were sex, age, skin color, marital status, education level, family income, leisure time physical activity, smoking, and self-reported health and nutritional status (body mass index and waist circumference). Multivariate analysis was performed from an a priori conceptual model.

1 Universidade do Vale do Rio dos Sinos, Unidade de Pesquisa e Pós-Graduação, Programa de Pós-Graduação em Saúde Coletiva. Av. Unisinos, 950, Bairro Cristo Rei, 93.022-750, São Leopoldo, RS, Brasil. Correspondência para/Correspondence to: MTS OLINTO. E-mail: <mtolinto@gmail.com>.

2 Universidade Federal do Rio Grande do Sul, Faculdade de Medicina, Departamento de Nutrição, Porto Alegre, RS, Brasil. Support: Conselho Nacional de Desenvolvimento Científico e Tecnologia (Processos no 477069/2009-6, 478366/2011-6, 307257/2013-4 e 303424/2011-7). 


\section{Results}

The prevalence of diabetes was $1.3 \%(95 \% \mathrm{Cl}=0.6-1.9)$. Type 2 diabetes Mellitus was associated with poor or regular self-reported health $(\mathrm{OR})=3.72 ; 95 \% \mathrm{Cl}=1.28-10.78)$ and level II abdominal obesity $\geq 102$ for men and $\geq 88$ for women (OR=5.76; $95 \% \mathrm{Cl}=1.07-29.10)$.

\section{Conclusion}

The prevalence of type 2 diabetes Mellitus was low. Moreover, the study evidenced the importance of using waist circumference to surveil and screen for metabolic diseases, such as type 2 diabetes Mellitus, and to monitor the low quality of life in the study individuals given the poor self-perceived health of workers with the said disease.

Keywords: Diabetes Mellitus, Type 2. Obesity abdominal. Occupational health. Workers.

\section{R E S U M O}

\section{Objetivo}

Investigar os fatores associados à diabetes Mellitus tipo 2 em trabalhadores de turnos de frigorífico de frango no sul do Brasil.

\section{Métodos}

Trata-se de um estudo transversal, com 1194 trabalhadores de ambos os sexos, com idade entre 18 e 50 anos. A presença de diabetes Mellitus tipo 2 foi avaliada por meio de autorrelato e confirmada pelo uso de medicação hipoglicemiante ou insulina. As variáveis independentes foram: sexo, idade, cor da pele, situação conjugal, escolaridade, renda familiar, atividade física de lazer, tabagismo, autopercepção de saúde e estado nutricional (indice de massa corporal e circunferência da cintura). Conduziu-se a análise multivariada, a partir de um modelo conceitual a priori.

\section{Resultados}

A prevalência de diabetes foi de 1,3\% (IC95\%: 0,6-1,9). A diabetes Mellitus tipo 2 esteve associada à autopercepção de saúde regular ou ruim ( $R O=3,72$; IC $95 \%$ 1,28-10,78) e à obesidade abdominal nível II - $\geq 102$ para homens e $\geq 88$ para mulheres $(R O=5,76 C(95 \% 1,07-29,10)$.

\section{Conclusão}

Foi encontrada baixa prevalência de diabetes Mellitus tipo 2. Além disso, evidenciou-se a importância do uso da medida de circunferência da cintura na vigilância e rastreamento de doenças metabólicas, como é o caso da diabetes Mellitus tipo 2, bem como a vigilância da baixa qualidade de vida desses indivíduos, por meio da autopercepção de saúde ruim dos trabalhadores com a patologia em questão.

Palavras-chave: Diabetes Mellitus tipo 2. Obesidade abdominal. Autopercepção de saúde. Trabalhadores.

\section{INTRODUCTION}

Type 2 Diabetes Mellitus (DM2) is a metabolic disease characterized by the lack or ineffectiveness of insulin. Studies show that diabetes increases the risk of developing vascular diseases, such as myocardial infarction and stroke $e^{1-4}$.

According to the International Diabetes Federation (IDF), there are 382 million diabetics in the world, exceeding, in 2012, the projections for 2030. Brazil ranks fourth country in the occurrence of diabetes, with a prevalence of $6.9 \%{ }^{5}$. However, there are no nationwide estimates of DM2 prevalence in Brazil, only selfreported measures have been used in nationwide studies.

The etiology of DM2 is multifactorial. The causes associated with its occurrence include sociodemographic factors, such as age, skin color, education level, and income; behavioral factors, such as eating habits, tobacco use, and physical inactivity; and body adiposity ${ }^{6-8}$. In addition, the 
workplace may function as an indirect contributing factor due to its characteristics, such as long working hours, stressing, insufficient occupational physical activity, and shift work ${ }^{9,10}$. The number of studies that investigated the occurrence of metabolic disorders in workers have increased ${ }^{11-14}$.

Type 2 diabetes Mellitus symptoms can interfere on workers' quality of life and productivity, and this is an important occupational health aspect. This study investigated the factors associated with DM2 in shift workers of a poultry processing plant in southern of Brazil.

\section{METHODS}

A cross-sectional study was conducted with a representative sample of 1,194 shift workers aged $18-50$ years. The subjects worked in the production line of a round-the-clock poultry processing plant in southern Brazil.

The sample size was calculated to assess the association between work shift and obesity ${ }^{12}$ based on the following presuppositions: confidence level of $95 \%$; statistical power of $80 \%$; unexposed: exposed ratio of $1: 2$ and risk ratio of $1: 30$. Sample size was increased by $10 \%$ to compensate for possible losses or refusals, so 1,125 workers were needed. All workers $(1,270)$ who resided in the municipality where the plant is located and two nearby municipalities, working in one of the three production sectors (cutting room, thermoprocessed foods, and evisceration) were considered eligible for the study. Pregnant workers and those on leave for more than 10 days during the study period were excluded. There were 76 losses and refusals, resulting in 1,194 workers who remained in the study.

Standardized, coded, and pretested questionnaires collected demographic, socioeconomic, behavioral, and outcome data. The presence of DM2 was assessed by the question: "Has any doctor ever told you that you have diabetes Mellitus?" An affirmative answer to this question was confirmed by the use of hypoglycemic drugs or insulin.

The study demographic and socioeconomic variables were sex (men/women), age (collected as a continuous variable sorted into three categories: 18-29 years, 30-39 years, and $\geq 40$ years), skin color (self-reported by the interviewees and categorized as white or other), education level (collected as a continuous variable and categorized as $\leq 4$ years, 5-10 years, and $\geq 11$ years), and family income (total income of each family member in the last month and categorized as tertiles (low, medium, high). The study behavioral variables were leisure-time physical activity (physically active: $\geq 150 \mathrm{~min} /$ week and inactive: <150min/week) ${ }^{15}$, smoking ("never smoked", "ex-smoker", and "smoker"), and selfrated health status (poor, regular, good, very good, and excellent), later categorized as good self-rated health (excellent, very good, and good) and regular/poor self-rated health (regular and poor).

The workers' nutritional status and abdominal obesity were investigated by anthropometry. Nutritional status was defined by body mass index $\left(\mathrm{BMl}=\mathrm{kg} / \mathrm{m}^{2}\right)$ and categorized as normal weight $\left(\leq 25.0 \mathrm{~kg} / \mathrm{m}^{2}\right)$, overweight $\left(25.0-29.9 \mathrm{~kg} / \mathrm{m}^{2}\right)$, and obese $\left(\geq 30.0 \mathrm{~kg} / \mathrm{m}^{2}\right)$. Weight was measured by the Fantasy Sunrise scale, digital model 2096PP (Toledo, São Paulo, Brazil) with capacity of $130 \mathrm{~kg}$ and accuracy of $100 \mathrm{~g}$. Height was measured by a stadiometer (SECA Bodymater 208, Hamburg, Germany) with a measuring range of $0-200 \mathrm{~cm}$ and accurate to $01 \mathrm{~mm}$.

Abdominal obesity was assessed measuring Waist Circumference (WC) at the midpoint between the lowest rib and iliac crest. The cut-off points were: appropriate $(<94 \mathrm{~cm}$ and $<80 \mathrm{~cm}$ for men and women, respectively), Level I (WC $\geq 94 \mathrm{~cm}$ to $<102 \mathrm{~cm}$ for men and $80 \geq$ to $<88 \mathrm{~cm}$ for women), and Level II $(\geq 102 \mathrm{~cm}$ and $\geq 88 \mathrm{~cm}$ for men and women, respectively) ${ }^{16}$.

Data were doubly entered into the software Epi Data version 3.1 (Epi Data, Odense, 
Denmark). The statistical analysis was performed by the software Stata version 11.0 (Stata Corporation, College Station, Texas, United States). The crude and adjusted odds ratios and respective $95 \%$ confidence intervals $(95 \% \mathrm{Cl})$ were estimated by logistic regression. The prevalence of DM2 was estimated to be lower than $6 \%$, allowing the use of logistic regression without overrating effect measures. For the adjusted analysis, a conceptual model of analysis was used in which the variables were grouped from the more distally to the more proximally related to type 2 diabetes Mellitus. Therefore, the first level included demographic and socioeconomic variables, the second level included behavioral variables, and the third level included anthropometric variables. Only variables with $p<0.20$ in the crude analysis were included in the adjusted analysis. Afterwards, the variables included in the adjusted analysis were controlled for all the other variables of the same level, and those that presented $p<0.20$ were maintained in the next level of analysis.

\section{RE S U L T S}

Among the 1,194 workers included in the study, most were females (65.1\%), aged 18-29 years $(54.9 \%)$, non-smokers $(85.8 \%)$, and physically inactive $(73.7 \%)$; most had white skin (83.8) and secondary education (48.0\%); and most presented good self-rated health (83.3\%). A total of $25.7 \%$ of the workers were overweight, and $9.4 \%$ were obese; $25.4 \%$ had abdominal obesity level I, and 23.0\%, level II (Table 1).

The prevalence of DM2 in the sample was $1.30 \%(95 \% \mathrm{Cl}=0.6-1.9)$. Among the study risk factors, there was a higher prevalence of DM2 in physically active workers (2.30\%; $95 \% \mathrm{Cl}=0.89,3.72)$ with regular/poor self-rated health $(3.50 \% ; 95 \mathrm{Cl} \% 0.90,6.10)$, and higher BMI $(2.68 \% ; 95 \% \mathrm{Cl}=0.01,5.71)$ and waist circumference $(2.91 ; 95 \% \mathrm{Cl}=0.91,4.91)$ (Table 1).

Table 2 shows the crude and adjusted odds ratios. After the adjustments, the variables that remained statistically associated were physical activity, self-rated health, and abdominal obesity. Workers with level II waist circumference $(\geq 102$ for men and $\geq 88$ for women) were almost six times more likely to have DM2 than those with normal waist circumference $(<94 \mathrm{~cm}$ for men and $<80 \mathrm{~cm}$ for women). Active workers and workers with regular/poor self-rated health were 3.7 times more likely to have DM2 than inactive workers or workers with good self-rated health.

\section{DISCUSSION}

The main finding of our study is the low prevalence of DM2 among workers, although it is strongly associated with abdominal obesity and poor or regular self-rated health, regardless of nutritional status.

The $1.3 \%$ prevalence of DM2 found among workers was lower than that found by a Brazilian nationally representative study $(6.9 \%)^{5}$, and similar to others found among workers of $1.2 \%{ }^{17}$ and $1.7 \%{ }^{18}$. This result may be explained by the healthy worker bias, i.e., relatively healthy people are or remain employed, whereas those with health problems are unemployed, retired, and/or unable to work. It should be pointed out that the symptoms of DM2 (polyuria, blurred vision, and others) may undermine productivity in the workplace. Therefore, the occurrence of DM2 may be a limitation for certain types of work that demand physical strength and long working hours, such as work performed in a poultry processing plant. Workers in large companies are periodically examined, which favors the diagnosis and prevention of chronic Noncommunicable Diseases (NCD). Moreover, these companies also allow workers to have at least one meal in the factory's canteen, thus providing a balanced energy and nutrient supply in at least one meal a day. Finally, self-report measures may underestimate DM2 prevalence ${ }^{19}$. All these aspects may contribute to a lower prevalence of DM2 in the workers of our sample.

The practice of physical activity as a protective factor against DM2 is well documented 
Table 1. Sample characteristics and prevalence of type 2 Diabetes Mellitus (DM2) according to sociodemographic, behavioral, and anthropometric characteristics of shift workers of a poultry processing plant in southern Brazil. $(n=1,194)$.

\begin{tabular}{|c|c|c|c|c|c|c|}
\hline \multirow{2}{*}{ Variable } & \multicolumn{2}{|c|}{ Sample } & \multicolumn{2}{|c|}{ DM2 } & \multirow{2}{*}{$95 \% \mathrm{Cl}$} & \multirow{2}{*}{$p$-value* } \\
\hline & $n$ & $\%$ & $n$ & $\%$ & & \\
\hline Sex & & & & & & 0.222 \\
\hline Male & 417 & 34.90 & 3 & 0.72 & $(0.01-1.53)$ & \\
\hline Female & 777 & 65.10 & 12 & 1.54 & $(0.67-2.41)$ & \\
\hline Age & & & & & & 0.085 \\
\hline 18 to 29 years & 644 & 53.90 & 4 & 0.62 & $(0.01-1.23)$ & \\
\hline 30 to 39 years & 319 & 26.70 & 7 & 2.19 & $(0.57-3.81)$ & \\
\hline$\geq 40$ years & 231 & 19.40 & 4 & 1.73 & $(0.03-3.40)$ & \\
\hline Skin color & & & & & & 0.284 \\
\hline White & 998 & 83.80 & 11 & 1.10 & $(0.45-1.75)$ & \\
\hline Non-white & 193 & 16.20 & 4 & 2.07 & $(0.04-4.10)$ & \\
\hline Education level (years) & & & & & & 0.218 \\
\hline$\leq 4$ years & 210 & 17.60 & 4 & 1.90 & $(0.01-3.80)$ & \\
\hline 5 to 10 years & 410 & 34.40 & 6 & 1.46 & $(0.30-2.63)$ & \\
\hline$\geq 11$ years & 573 & 48.00 & 5 & 0.87 & $(0.01-1.63)$ & \\
\hline Family income (tertile) & & & & & & 0.319 \\
\hline Low & 405 & 34.30 & 4 & 0.99 & $(0.01-1.95)$ & \\
\hline Average & 388 & 32.40 & 4 & 1.05 & $(0.02-2.10)$ & \\
\hline High & 393 & 33.30 & 7 & 1.78 & $(0.47-3.10)$ & \\
\hline Smoking status & & & & & & 0.072 \\
\hline Never smoked & 1023 & 85.80 & 10 & 0.98 & $(0.37-1.58)$ & \\
\hline Former smoker & 110 & 9.20 & 3 & 2.73 & $(0.01-5.81)$ & \\
\hline Smoker & 60 & 5.00 & 2 & 3.33 & $(0.01-8.00)$ & \\
\hline Physical activity & & & & & & 0.027 \\
\hline Physically inactive & 760 & 63.70 & 5 & 0.66 & $(0.08-1.23)$ & \\
\hline Physically active & 434 & 36.40 & 10 & 2.30 & $(0.89-3.72)$ & \\
\hline Self-perceived health & & & & & & 0.006 \\
\hline Good & 994 & 83.30 & 8 & 0.80 & $(0.24-1.40)$ & \\
\hline Regular/Poor & 200 & 16.80 & 7 & 3.50 & $(0.90-6.10)$ & \\
\hline Nutritional status (BMI) & & & & & & 0.036 \\
\hline Normal $\left(\leq 24.9 \mathrm{~kg} / \mathrm{m}^{2}\right)$ & 775 & 64.90 & 6 & 0.77 & $(0.01-1.40)$ & \\
\hline Overweight ( 25 to $29.9 \mathrm{~kg} / \mathrm{m}^{2}$ ) & 307 & 25.70 & 6 & 1.95 & $(0.04-3.51)$ & \\
\hline Obese $\left(\geq 30 \mathrm{~kg} / \mathrm{m}^{2}\right)$ & 112 & 9.40 & 3 & 2.68 & $(0.01-5.71)$ & \\
\hline Waist circumference** & & & & & & 0.003 \\
\hline Normal & 615 & 51.60 & 3 & 0.49 & $(0.01-1.04)$ & \\
\hline Level I & 303 & 25.40 & 4 & 1.32 & $(0.03-2.61)$ & \\
\hline Level II & 275 & 23.00 & 8 & 2.91 & $(0.91-4.91)$ & \\
\hline
\end{tabular}

Note: "Fisher's Exact Test for heterogeneity of proportions (categorical variables) and linear trend (ordinal variables); ** Normal: $Q<80 \mathrm{~cm}$ and $\mathrm{O}^{\prime \prime}<94 \mathrm{~cm}$, Level I: $Q \leq 80 \mathrm{~cm}$ to $<88 \mathrm{~cm}$ and $\mathrm{O}^{\prime \prime} \leq 94 \mathrm{~cm}$ to $<102 \mathrm{~cm}$, Level II: $\mathrm{q} \geq 88 \mathrm{~cm}$ and $\mathrm{O}^{\prime \prime} \geq 102 \mathrm{~cm}$.

95\% Cl: 95\% Confidence Interval; BMI: Body Mass Index.

in the literature $20-22$. A systematic review evaluated the evidence from ten prospective studies, including a total of 301,221 adults and 9,367 incident cases, and follow-ups ranging from four to 17 years. The review found that moderate physical activity protected against the risk of type
2 diabetes $^{20}$. However, in our study, DM2 was associated with the practice of 150 minutes or more of physical activity per week. Our finding may probably be explained by reverse causality. Physically-active workers may have been physically inactive for almost all their lives but changed their 
Table 2. Crude and adjusted Odds Ratios (OR) and their respective Confidence Intervals ( $95 \% \mathrm{Cl}$ ) for type 2 Diabetes Mellitus (DM2) according to sociodemographic, behavioral, and anthropometric characteristics of shift workers of a poultry processing plant in southern Brazil. $(n=1,194)$.

\begin{tabular}{|c|c|c|c|c|}
\hline \multirow{2}{*}{ Variable } & \multicolumn{2}{|c|}{ Crude analysis } & \multicolumn{2}{|c|}{ Adjusted analysis } \\
\hline & $\mathrm{OR}(95 \% \mathrm{Cl})$ & $p$-value* & OR $(95 \% \mathrm{Cl})$ & $p$-value* \\
\hline \multicolumn{5}{|l|}{$1^{\circ}$ Level $^{* *}$} \\
\hline \multicolumn{5}{|l|}{ Sex } \\
\hline Male & 1 & 0.234 & - & \\
\hline Female & $2.16(0.61-7.71)$ & & & \\
\hline \multicolumn{5}{|l|}{ Age } \\
\hline 18 to 29 years & 1 & 0.093 & 1 & 0.093 \\
\hline 30 to 39 years & $3.59(1.04-12.35)$ & & $3.58(1.04-12.35)$ & \\
\hline$\geq 40$ years & $2.82(0.70-11.37)$ & & $2.82(0.70-11.36)$ & \\
\hline \multicolumn{5}{|l|}{ Skin color } \\
\hline White & 1 & 0.276 & & \\
\hline Non-white & $1.90(0.60-6.03)$ & & - & \\
\hline \multicolumn{5}{|l|}{ Education level (years) } \\
\hline$\leq 4$ years & $2.21(0.59-8.29)$ & 0.223 & & \\
\hline 5 to 10 years & $1.69(0.51-5.57)$ & & - & \\
\hline$\geq 11$ years & 1 & & & \\
\hline \multicolumn{5}{|l|}{ Family income (tertile) } \\
\hline Low & 1 & 0.323 & & \\
\hline Average & $1.06(0.26-4.27)$ & & & \\
\hline High & $1.82(0.53-6.26)$ & & - & \\
\hline \multicolumn{5}{|l|}{$2^{\circ}$ Level $^{* *}$} \\
\hline \multicolumn{5}{|l|}{ Smoking status } \\
\hline Never smoked & 1 & 0.123 & 1 & 0.113 \\
\hline Former smoker & $2.84(0.77-10.48)$ & & $2.07(0.53-7.98)$ & \\
\hline Smoker & $3.49(0.75-16.31)$ & & $3.29(0.70-16.29)$ & \\
\hline \multicolumn{5}{|l|}{ Physical activity } \\
\hline Physically inactive & 1 & 0.021 & 1 & 0.024 \\
\hline Physically active & $3.56(1.21-10.49)$ & & $3.50(1.16-10.48)$ & \\
\hline \multicolumn{5}{|l|}{ Self-perceived health } \\
\hline Good & 1 & 0.004 & 1 & 0.014 \\
\hline Regular/Poor & $4.47(1.60-12.47)$ & & $3.72(1.28-10.78)$ & \\
\hline \multicolumn{5}{|l|}{$3^{\circ}$ Level $^{* *}$} \\
\hline \multicolumn{5}{|l|}{ Nutritional status (BMI) } \\
\hline Normal $\left(\leq 24.9 \mathrm{~kg} / \mathrm{m}^{2}\right)$ & 1 & 0.042 & 1 & 0.726 \\
\hline Overweight ( 25 to $29.9 \mathrm{~kg} / \mathrm{m}^{2}$ ) & $2.55(0.82-7.98)$ & & $0.85(0.20-3.53)$ & \\
\hline Obese $\left(\geq 30 \mathrm{~kg} / \mathrm{m}^{2}\right)$ & $3.53(0.87-14.31)$ & & $0.78(0.13-4.53)$ & \\
\hline \multicolumn{5}{|l|}{ Waist circumference ${ }^{* * *}$} \\
\hline Normal & 1 & 0.006 & 1 & 0.040 \\
\hline Level I & $2.73(0.61-12.27)$ & & $3.55(0.68-14.15)$ & \\
\hline Level II & $6.11(1.61-23.22)$ & & $5.76(1.07-29.10)$ & \\
\hline
\end{tabular}

Note: "Logistic regression: Wald test to heterogeneous proportions (categorical variables) and linear trend (ordinal variables); ${ }^{* *}$ Adjusted for other variables of the same level and maintained at the next level of analysis when $p<0.20$; ${ }^{* * *}$ Normal: $ᄋ<80 \mathrm{~cm}$ and $\sigma^{*}<94 \mathrm{~cm}$; Level I: O $\leq 80 \mathrm{~cm}$ to $<88 \mathrm{~cm}$ and $\sigma^{\prime \prime} \geq 94 \mathrm{~cm}$ to $<102 \mathrm{~cm}$; Level II: $ᄋ \geq 88 \mathrm{~cm}$ and $\sigma^{\prime \prime} \geq 102 \mathrm{~cm}$. $p$-value for Hosmer-Lemeshow test=0.98.

95\% Cl: 95\% Confidence Interval; BMI: Body Mass Index.

lifestyle when they were diagnosed with DM2 as healthcare professionals strongly recommend diabetics to exercise.
The workers who rated their health as regular/poor were more prone to having DM2 than those who rated their health as good. This 
result is expected, since the presence of DM2 may cause many symptoms, such as thirst, polyuria, blurred vision, weight loss, and hyperphagia. In its most severe forms, it may cause ketoacidosis or nonketotic hyperosmolar syndrome, drastically diminishing the quality of life of the affected individuals ${ }^{23,24}$. These associations have already been observed in other studies ${ }^{25,26}$.

Abdominal obesity was associated with DM2 regardless of workers' BMI. Metabolic complications associated with obesity were not only related to excess weight, but also, and mainly, to the distribution of body fat. In this sense, studies have shown that localized fat in the central region of the body, particularly visceral adiposity, has a greater influence on the development of NCD, such as DM2, as it is a reflection of a pathological state associated with metabolic diseases ${ }^{27-30}$. Waist circumference is the anthropometric measure most strongly correlated with the quantity of visceral adipose tissue ${ }^{28-30}$. Thus, occupational health professionals may incorporate waist circumference measurement in their routine evaluations as it is an important marker of cardiometabolic risk.

Some limitations of this study, such as reverse causality and the healthy worker bias, have already been discussed. Another possible limitation is the use of self-reported measures for measuring the outcome. However, self-reported measures of NCD have been widely used in prevalence studies. In Brazil' important nationally representative epidemiological studies, such as the Vigilância de Fatores de Risco e Proteção para Doenças Crônicas por Inquérito Telefônico (VIGITEL, Telephone Survey on Chronic Noncommunicable Disease Protective and Risk Factors, Brasilia, Distrito Federal, Brazil) and the Programa Nacional por Amostra de Domicilio (PNAD, National Household Sample Survey), have employed the same methodology ${ }^{5,31}$. It should also be highlighted that, based on the sample size $(n=1,194)$, a $1.5 \%$ prevalence of DM2 could be observed, considering a confidence level of $95.0 \%$, an acceptable error of 1 percentage point, and a statistical power of $80.0 \%$ to detect a prevalence ratio of 3.8 between DM2 and its associated factors. Finally, a conceptual model was used in adjusted analysis; however, the variables included in this model explained only $16.0 \%$ of the outcome (pseudo-R2=0.16).

\section{CONCLUSION}

The results of this study point to a greater prevalence of DM2 in workers with abdominal obesity, reinforcing it as an important predictive factor for this disease. In this sense, the efficiency and practicality of waist circumference as a screening measure for workers should be highlighted. In addition, most diabetic workers rated their health status as regular/poor, showing that the symptoms of DM2 decreases the quality of life of its carriers, which may result in loss of productivity in the work place and, therefore, exclusion from the labor market. Thus, in addition to preventive DM2 actions, workers who already have diabetes should receive special care in order to avoid the worsening of the disease, preserve their quality of life, and prevent exclusion from the labor market.

\section{A C KNOWLEDGMENTS}

This study was sponsored by Conselho Nacional de Desenvolvimento Científico e Tecnológico. C FRÖHLICH receives a student grant from Coordenação de Aperfeiçoamento de Pessoal de Nível Superior. MTA OLINTO and MP PATTUSSI received research productivity grants from Conselho Nacional de Desenvolvimento Científico e Tecnológico.

CONTRIBUTORS

All authors participated in all phases of the research.

\section{REFERE NCES}

1. Sarwar N, Gao P, Seshasai SR, Gobin R, Kaptoge S, Di Angelantonio $\mathrm{E}$, et al. Diabetes mellitus, fasting 
blood glucose concentration, and risk of vascular disease: A collaborative meta-analysis of 102 prospective studies. Lancet. 2010; 375(9733):2215-2 2. http://dx.doi.org/10.1016/S0140-6736(10)604 84-9

2. Kannel WB, McGee DL. Diabetes and cardiovascular risk factors: The Framingham study. Circulation. 1979; 59(1):8-13. http://dx.doi.org/10.1161/01. CIR.59.1.8

3. Oliveira DS, Tannus LR, Matheus AS, Correa FH, Cobas R, Cunha EF, et al. Evaluation of cardiovascular risk according to Framingham criteria in patients with type 2 diabetes. Arq Bras Endocrinol Metabol. 2007; 51(2):268-74. http://dx.doi.org/10.1590/S0 004-27302007000200015

4. Roger VL, Go AS, Lloyd-Jones DM, Adams RJ, Berry JD, Brown TM, et al. Heart disease and stroke statistics-2011: A report from the American Heart Association. Circulation. 2011; 123(4):e18-e209. http://dx.doi.org/10.1161/CIR.0b013e3182009 701

5. Brasil. Ministério da Saúde. Vigilância de fatores de risco e proteção para doenças crônicas por inquérito telefônico. Brasília: Secretaria de Vigilância Epidemiológica; 2015.

6. Moraes SA, Freitas ICM, Gimeno SGA, Mondini L. Prevalência de diabetes Mellitus e identificação de fatores associados em adultos residentes em área urbana de Ribeirão Preto, São Paulo, Brasil, 2006: Projeto OBEDIARP. Cad Saúde Pública. 2010; 26:929-41. http://dx.doi.org/10.1590/S0102-31 $1 \times 2010000500015$

7. Mielczarski RG, Costa JS, Olinto MT. Epidemiology and organization of health services: diabetes Mellitus in a community of the city of Porto Alegre. Cien Saúde Colet. 2012; 17(1):71-8. http://dx.doi. org/10.1590/S1413-81232012000100010

8. Morimoto A, Ohno Y, Tatsumi Y, Mizuno S, Watanabe $S$. Effects of healthy dietary pattern and other lifestyle factors on incidence of diabetes in a rural Japanese population. Asia Pac J Clin Nutr. 2012; 21(4):601-8. http://dx.doi.org/10.1590/S0 102-311X2010000500015

9. OLINTO MTA, Canuto R, Garcez AS. Work and Abdominal Obesity Risk. In: Watson, RR, Organizador. Nutrition in the prevention and treatment of abdominal obesity. San Diego: Elsevier; 2014, p.17-25.

10. Kawabe $Y$, Nakamura $Y$, Kikuchi S, Suzukamo $Y$, Murakami Y, Tanaka $T$, et al. Relationship of type of work with health-related quality of life. Qual Life Res. 2015; 24(12):2927-32. http://dx.doi.org/10. 1007/s11136-015-1024-5

11. Rodrigues TC, Canani LH. The influence of the work shift in patients with type 2 diabetes. Rev Assoc
Med Bras. 2008; 54(2):160-2. http://dx.doi.org/10. 1590/S0104-42302008000200021

12. Macagnan J, Pattussi MP, Canuto R, Henn RL, Fassa $A G$, Olinto MT. Impact of nightshift work on overweight and abdominal obesity among workers of a poultry processing plant in southern Brazil. Chronobiol Int. 2012; 29(3):336-43. http://dx.doi. org/10.3109/07420528.2011.653851

13. Silva-Costa A, Rotenberg L, Coeli CM, Nobre AA, Harter Griep R. Night work is associated with glycemic levels and anthropometric alterations preceding diabetes: Baseline results from ELSA-Brasil. Chronobiol Int. 2016; 5:1-9. http://dx.doi.org/10. 3109/07420528.2015.1115765

14. Jermendy G, Nadas J, Hegyi I, Vasas I, Hidvegi T. Assessment of cardiometabolic risk among shift workers in Hungary. Health Qual Life Outcomes. 2012; 10:18. http://dx.doi.org/10.1186/1477-75 25-10-18

15. Department of Health and Human Services. Physical Activity Guidelines for Americans. Washington. (DC): HHS; 2008.

16. World Health Organization. Obesity: Preventing and managing the global epidemic. Report of a WHO consultation on obesity; Geneva: WHO; 2000. p. 253.

17. Thabit H, Burns N, Shah S, Brema I, Crowley V, Finnegan $\mathrm{F}$, et al. Prevalence and predictors of diabetes and cardiometabolic risk among construction workers in Ireland: The construction workers health trust screening study. Diab Vasc Dis Res. 2013; 10(4):337-45. http://dx.doi.org/10.11 77/1479164113479808

18. Guariguata L, Beer I, Hough R, Bindels E, WeimersMaasdorp D, Feeley FG, et al. Diabetes, HIV and other health determinants associated with absenteeism among formal sector workers in Namibia. BMC Public Health. 2012; 12:44. http://dx. doi.org/10.1186/1471-2458-12-44

19. Okura Y, Urban LH, Mahoney DW, Jacobsen SJ, Rodeheffer RJ. Agreement between self-report questionnaires and medical record data was substantial for diabetes, hypertension, myocardial infarction and stroke but not for heart failure. J Clin Epidemiol. 2004; 57(10):1096-103. http://dx. doi.org/10.1016/j.jclinepi.2004.04.005

20. Jeon CY, Lokken RP, Hu FB, van Dam RM. Physical Activity of moderate intensity and risk of type 2 diabetes. A systematic review. Diabetes Care. 2007; 30(3):744-52. http://dx.doi.org/10.2337/dc06-1 842

21. Saleh F, Mumu SJ, Ara F, Hafez MA, Ali L. Non-adherence to self-care practices \& medication and health related quality of life among patients with 
type 2 diabetes: A cross-sectional study. BMC Public Health. 2014; 14:431. http://dx.doi.org/10.1186/14 71-2458-14-431

22. Hamasaki H. Daily physical activity and type 2 diabetes: A review. World J Diabetes. 2016; 7(12):243-51. http://dx.doi.org/10.4239/wjd.v7.i12. 243

23. Abegunde DO, Mathers CD, Adam T, Ortegon M, Strong K. The burden and costs of chronic diseases in low-income and middle-income countries. Lancet. 2007; 370(9603):1929-38. http://dx.doi. org/10.1016/S0140-6736(07)61696-1

24. Sociedade Brasileira de Diabetes. Diretrizes da Sociedade Brasileira de Diabetes: 2013-2014. São Paulo: AC pharmaceutical; 2014.

25. Rubin RR, Peyrot M. Quality of life and diabetes. Diabetes Metab Res Rev. 1999; 15(3):205-18. http:// dx.doi.org/10.1002/(SICI)1520-7560

26. Peres MA, Masiero AV, Longo GZ, Rocha GCd, Matos IB, Najnie K et al. Auto-avaliação da saúde em adultos no Sul do Brasil. Rev Saúde Pública. 2010; 44:901-11. http://dx.doi.org/10.1590/S00 34-89102010000500016

27. Patel PS, Buras ED, Balasubramanyam A. The role of the immune system in obesity and insulin resistance. J Obes. 2013; 2013:616193. http://dx. doi.org/10.1155/2013/616193

28. Pinto-Sietsma SJ, Navis G, Janssen WM, Zeeuw D, Gans RO, Jong PE et al. A central body fat distribution is related to renal function impairment, even in lean subjects. Am J Kidney Dis. 2003; 41(4):733-41. http://dx.doi.org/http://dx.doi.org/ 10.1016/S0272-6386(03)00020-9

29. Wang YF, Rimm EB, Stampfer MJ, Willett WC, Hu FB. Comparison of abdominal adiposity and overall obesity in predicting risk of type 2 diabetes among men. Am J Clin Nutr. 2005; 81(3):555-63.

30. Yang J, Kang J, Guan Y. The mechanisms linking adiposopathy to type 2 diabetes. Front Med. 2013; 7(4):433-44. http://dx.doi.org/10.1007/s11684-01 3-0288-9

31. Instituto Brasileiro de Geografia e Estatística. Pesquisa Nacional por Amostra de Domicílios. Rio de Janeiro: IBGE; 2011.
Received: December 15, 2015 Final version: July 12, 2016 Approved: August 12, 2016 
